\title{
DECOLONISING THE CURRICULUM TO REINVIGORATE EQUITY IN HIGHER EDUCATION: A LINGUISTIC TRANSFORMATION
}

\author{
M. W. Lumadi \\ Department of Curriculum and Instructional Studies \\ University of South Africa \\ Pretoria, South Africa \\ e-mail: Lumadmw@unisa.ac.za / https://orcid.org/0000-0003-0121-7386
}

\section{ABSTRACT}

This article outlines the severity of historical injustices in the South African Higher Education system and introduces the key concepts that underpin the argument. Reporting on a series of interviews will be provided to demonstrate how these injustices continue to be perpetuated. "The subject of dissension" regarding "decolonisation" insinuates that the universities implicated in the study are colonial; "they are an integral part" of an empire that has a role in preserving fixed values for the wellbeing of an elite. This elite has the racial connotation of being white. Whiteness is an avenue for preserving their opulence and echelon within an ideological, theocratic capitalist modus operandi. This wrangle is disingenuous and ahistorical. Despite the revised language policy that seeks to promote multilingualism and facilitate inclusivity, social cohesion and meaningful participation by all students through focusing on previously marginalised languages, the associated institutions' curricula, reproduce the community's wider inequalities.

Keywords: decolonisation, curriculum equity, higher education institutions, language transformation

\section{INTRODUCTION}

The degree of difficulty, that besets any scholar who attempts to propose a measurable and context-specific decolonisation of the curriculum for addressing transformation; in the democratic South African higher education system can vary. There has never been nor will there ever be an acceptable and common agreement among all universities regarding what constitutes the decolonisation of curriculum. There is a plethora of stakeholders with divergent interests and viewpoints, and the debate as to what constitutes decolonisation and curriculum transformation differs from year to year and from one scholar to another. This simply denotes that the discourse of decolonisation is theoretically limited.

A commonly observed trend among South African universities is the relative underachievement of minorities in the academic realm. The usual and often lazily regurgitated clarification for this phenomenon revolves around the socio-economic conditions in which the minority groups find themselves, contributing to their academic plight. While this deserves 
some credit, it does not tell the entire story. Apart from the general socio-economic status of many social groups, minorities often engage with academic communities that do not even remotely mirror their cultural habitus (Oelofsen 2015, 140).

Le Grange $(2014,1288)$ propounded that decolonisation as a language of resistance has a detailed history in the struggle for human rights, social justice and equality. Scholars have argued that the rise of white supremacists was only to be expected given the proliferation of identity politics in higher education. Although abuse of power by academics on students or students on academics is rife, it is gratuitous. The inadequacy of existing policies and procedures for exposing and addressing the abuse of power has been brought to public attention at South African higher education institutions (Fataar 2018, vii).

A truly democratic education must not be ideologically neutral; rather, it must ardently pursue the preparation of students for engaged citizenship in an ostensibly democratic society. Whether the leadership of historically white institutions will gather the institutional zeal and the moral and ethical courage to provoke and institute real, substantive institutional transformation is unknown. The first stride in this direction, however, is to drive equity and justice, the yardstick by which leadership measures progress rather than merely diversity and inclusion (Sayed, Motala and Hoffman 2017, 83).

Waghid $(2014,59)$ takes a step further and argues that African philosophy of education is invariably aimed at addressing the continent's injustices and inequalities. A university education that is guided by a concern for educational justice, an advocacy for freedom, autonomy, democratic engagement and responsiveness to the other is one that takes African philosophy of education seriously. A social just curriculum needs to draw upon the vernacular knowledge of marginalised groups to produce truly powerful knowledge and a social justice curriculum.

\section{LITERATURE REVIEW}

Decolonising the curriculum is about embedding liberation and equality in all aspects of higher education from changing course content, changing the language of teaching if it benefits the minority at the expense of the majority, changing the way courses are taught, updating assessment techniques, developing research and publication practices, supporting training, resources and funding and modifying recruitment criteria (Saunders 2017; UNESCO 2003, 108). A decolonised curriculum would provide different perspectives on topics, encourage critical thinking and initiate debate leading to discussions on issues that are important to marginalised groups in our community but are usually never addressed in the education systems. 
Many students and academic staff refuse to engage in the robust debates of curriculum decolonisation. Some staff ridicule students' demands for a multiplicity of knowledge systems by debunking them as inferior to Western theories. Most academics have heeded the call for an African-centred curriculum by mentioning that this would render South Africa's universities parochial (Vandeyar 2019, 10).

Language plays a prominent role in the development of personal, social and cultural identity. Students with a strong foundation in their first language often display a deeper understanding of themselves and their place within society in addition to an increased sense of well-being and confidence. Naturally, this filters down into every aspect of their lives, including their academic achievement (Odora-Hoppers and Pinar 2017, 9).

As people go on to cherish the period of colonisation while failing to recognise the sadistic and vicious treatment of local communities, this has a deleterious effect on our society. This occurred during the period that included forced adoption of oppressive language, slavery, racial and religious segregation. To teach a curriculum that is fair and transformed and does not view topics through a Eurocentric lens only, scholars need to be transformed. Higher education institutions should deliver mandatory liberation and equality training to all staff. They should also employ academic and professional staff with liberation backgrounds and provide them with good working conditions, so they can prosper and thrive in their careers (Pandey and Moorad 2003, 147).

\section{THE 3D PEDAGOGY FRAMEWORK}

The study is underpinned by the strategic $3 D$ Pedagogy framework of inclusive teaching practice developed by Gabriel $(2020,31)$. The term "decolonising the curriculum" has become fashionable within United Kingdom Higher Education. Initially embraced by student activists reviewing Euro-centricity, recently the concept has been appropriated by higher education institutions as integral element of their corporate repertoire alongside diversity, depoliticizing, distorting its authentic meaning and disconnecting it from the cause of social justice as reflected in Figure 1. There is a student component enabling them to contribute to curriculum development.

The genesis of decolonisation is far removed from the Ivory Tower; since decoloniality is a critical standpoint and movement with origins in South and Latin America, led by indigenous and Afro-descendant scholar activists. Their intentions are not only to challenge Eurocentric modes of thinking inextricably linked to slavery, colonialism and modernity but to construct and advance mindset, knowing and doing from the intellectual production that emerges from the lived experience of the colonized (Gabriel 2019, 1461). 


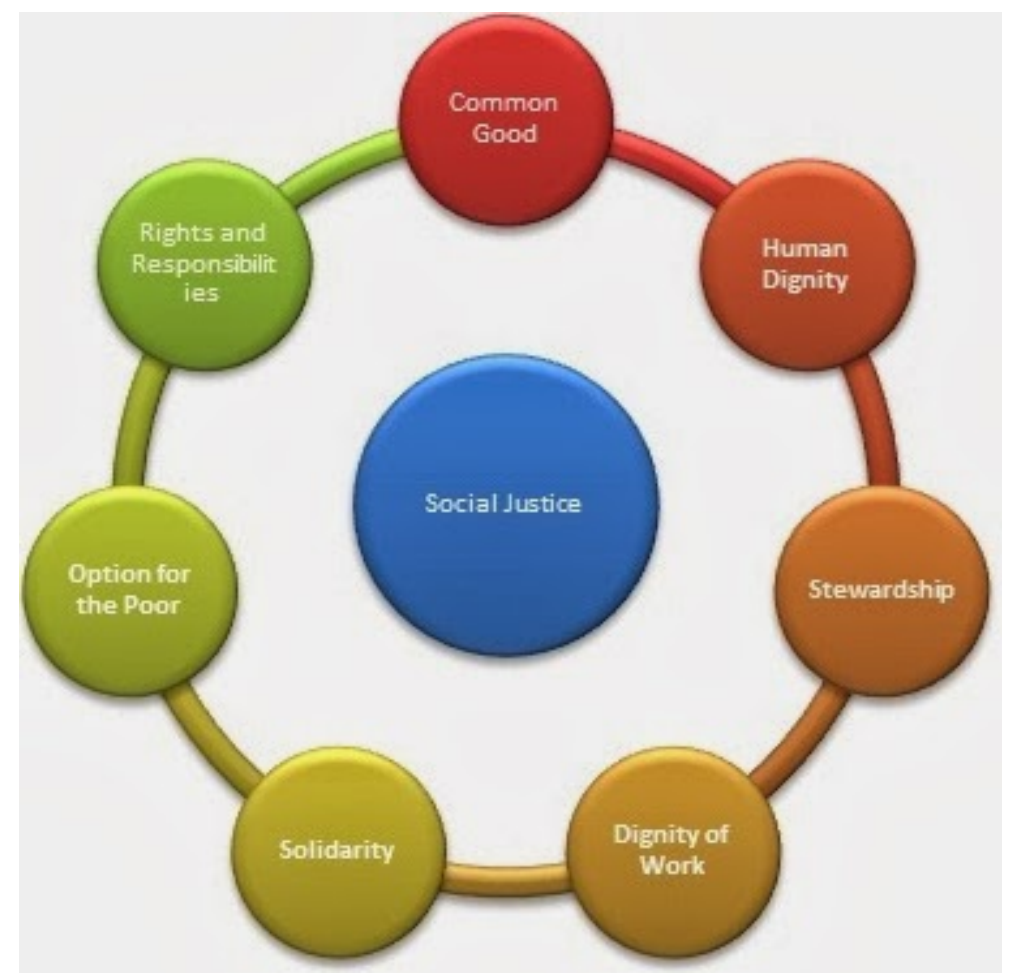

Figure 1: Social justice

Social transformation can only be achieved through the adoption of an integral approach involving both the staff and students like the 3D Pedagogy Framework, a tripartite model that advances cultural democracy, diversification of content, teaching styles and teaching personnel. In common with diversity, decolonisation is inconsequential unless it forms part of an institution wide programme of strategic matters delivering infrastructural changes to educational and academic practice that include policy reform and accountability at all levels of the institution. These critical interventions are critical to disrupt dominant norms that privilege White, European identity and perpetuate racial inequality in higher education (Hargreaves 1988, 37).

Throughout the ages, there has been a continuous struggle between the classes of the "haves" and the "have nots" in the pretext of social justice. In every stage of human society; the "have nots" have been exploited by the "have" classes and could not attain justice, since the problem of exploitation is rooted in superiority of language and power dynamics. Strictly speaking, in the existing social system based on dominance of the less privileged, in which one is boss and the other is slave, true justice is not possible, and it is thus impossible to stop the exploitation (Mudaly 2018, 57; Nabudere 2011, 66). 


\section{METHODOLOGY}

The following research questions were explored:

- How does decolonisation of the curriculum from South Africa Higher Education institutions; with a language policy of Afrikaans, promote inequality in the wider community?

- Which curriculum challenges beset universities when students and staff are deprived equal educational opportunities to flourish and succeed?

A qualitative research approach was adopted in this study (Silverman 2012, 78), drawing information on decolonisation of the curriculum from two universities with a language policy of Afrikaans as a medium of instruction and learning in the post-apartheid era. The fact that the research was conducted during the period of the unprecedented Coronavirus (COVID-19) pandemic compelled the researcher to resort to telephone interviews with executive deans, students and academics. It was impossible for one to visit the institutions because all participants were operating from home and relying on technology. Students were invited on Facebook, twitter and WhatsApp, and they responded positively. Key participants were the executive deans from two implicated universities in different South African provinces.

Such informants "provided experiences on the reasons behind using Afrikaans" at their universities and the challenges besetting them in management. The second source of information consisted of documentary sources. These included scholarly work and official documents. The literature mainly focused on the language policy in the identified universities. The third source of information for the current study was eight black students and eight lecturers, four apiece from each institution. All were non-Afrikaans language speakers. The study utilised data source triangulation. Purposive sampling and convenience sampling were used in the selection of the key informants.

Initially, the researcher sought administrators with experience in the management of faculties who would interrogate the issues of the decolonisation of the curriculum and the transformation at higher education institutions from positions of authority. The administrators were in their second terms of office, having nine and ten years' experience as executive deans in the universities involved in the study. Their positions of deanship were valid for five years. Convenience sampling was the most appropriate method for easy access to the nearest key informants. Triangulation of data sources, therefore, addressed the demerits of relying solely on three key informants. On the one hand, of the black students, four were registered for undergraduate studies and four for postgraduate studies in various faculties. On the other hand, 
the academics had ten years' experience and above. Two of them were lecturers, two were senior lecturers, two were associate professors and two were full professors.

The responses of the interviewees concerned the implications of using Afrikaans as a medium of instruction. All sources of information were acknowledged in line with ethical practices. While the scholarly works were cited according to authors' names, from the interviews with the key informants, the researcher identified and captured the sensitive language issues that were raised. From the documentary sources, relevant statements were captured and quoted. All sources of information were adequately acknowledged. The information supplied by the key informants of the study provided first-hand experience. The Executive Deans, who were allocated the pseudonyms ED X and ED Y to conceal their identity, served as senior managers at two institutions referred to as Universities A and B respectively. The assigning of letters C, D and E for students or F and G, for lecturers, H and I for senior lecturers ensured the anonymity of the participants.

Evolving from the thematic analysis undertaken which was informed by theory-driven and data-driven type of analysis, the following themes were identified: lecturing and assessment, appointment practices and meetings and publication of research in Afrikaans. Principles of curriculum design; encourage lecturers and students to consider how new thinking influences curriculum deliberations, development and implementation. The themes also reflect the university's values, context, pedagogy and needs. Curriculum design is a concept used to describe the purposeful, deliberate and systematic organisation of the curriculum within a class (Lumadi 2000, 289). A mere glance at the themes shows that the principles of curriculum design presented in Figure 2 were overlooked.

\section{THEMES}

Democratic South Africa has 11 official languages, namely IsiZulu, IsiXhosa, IsiSwati, IsiNdebele, SeSotho, Setswana, Sepedi, Tshivenda and Xitsonga, hereafter referred to as African languages, in addition to Afrikaans and English, which were introduced by the colonisers. It is imperative to bear in mind that language and politics are very much intertwined in South Africa, as they are worldwide. The slant of the Verwoerdian policy of divide-and-rule; towards black language policy was allied to the entire demeaning system of laws, that kept black people languishing in permanent poverty. It is evident from the themes presented below that despite the advent of democracy, some universities are still procrastinating the process of transformation. Such universities use Afrikaans, which still completely divides the student population. The use of Afrikaans is a barrier that is used as an instrument to keep the student body of higher education institutions white and affluent. Systemic and structural discrimination 
in addition to overt and covert racism remains an issue of institutional culture.

\section{Principles in Curriculum Design}

Components in Curriculum Design
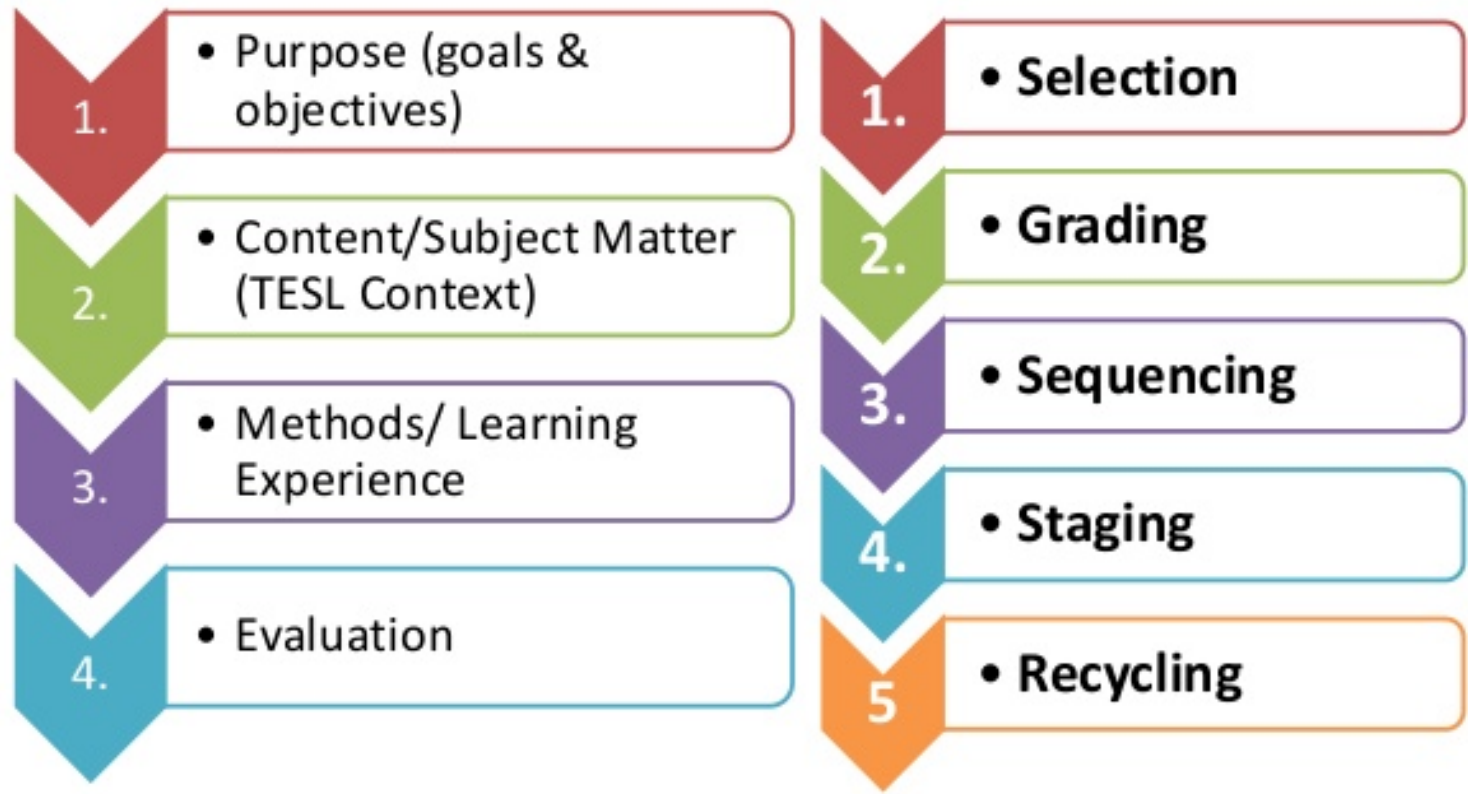

(Ornstein \& Hunkins, 2014)

Figure 2: Principles in curriculum design

\section{Lectures and assessment}

In the defunct apartheid era, black students were denied access to higher education institutions and were only allowed to register with the so-called historically black universities in the homelands. These were universities of the North, now known as the University of Limpopo and the University of Zululand, the University of the Transkei, now known as Walter Sisulu University, the University of Bophuthatswana "Unibo", now known as North-West University and others. The abolishment of apartheid in South Africa in 1994 permitted black students to register with the so-called lily-white universities. Afrikaans universities were coerced to accept the ethos of multiculturalism and along with their English-language counterparts, to move rapidly in the direction of reflecting the racial demography of the country within their rules.

Despite the long history of agony and anguish for curriculum reform, the implicated higher education institutions are still dawdling, and it is perturbing. Although the country is more than 26 years into democracy, in some universities, lectures in a multicultural hall are still conducted 
in Afrikaans. In some instances, lectures are presented in English and Afrikaans concurrently. This is a student-centred approach that brings students to the centre of the curriculum process; there are robust debates about the role that universities play in African society and the type of graduates they intend to produce. "Tolk diens" meaning interpreter service or simulation translation has been implemented to appease black and non-Afrikaans-speaking students. However, this service is unreliable and leaves black students discontented.

Students C, D and E were in concord during their interviews regarding the statement of a Student who deplored,

"Employment in the translation services is strictly meant for Afrikaans students and this is a way of boosting them financially, because for each session their bank accounts are flushed. Study materials and question papers for undergraduate and postgraduate programmes are in both languages. Dissertations and theses too are written in such languages. Other African languages are belittled and there was an incident where an altercation ensued between black and white students."

This inclination is rather menacing because the simulation translation led to unfair discrimination. African languages are deprived of a space at higher education institutions. They are marginalised in many lecture halls and assessments. This controversial issue is in our collective history; colonialism brainwashed our minds to hold everything that is African in disdain. This includes our languages, cultures and religions. It is high time that black individuals claim the academic space as part of the transformation and Africanisation of the curriculum. It is hardly a radical notion because the rest of the so-called first world demands recognition of mother tongues. The British learn in English, Italy teaches and learns in Italian, Spain teaches and learns in Spanish and Germans teach and learn in German. In Africa, we learn largely through foreign languages such as English, Portuguese and French. In the teaching learning situation, African languages for teaching and learning should not be excluded when providing interpretation services.

Clarity of language is especially vital because equity is often confounded with equality. As a certain scholar at the Wisconsin University remarked,

"I used to think that equity means you treat everyone equally, but now I see it more in terms of outcomes. Are students able to achieve similar results at the end of their education irrespective of posing the following questions; Where and when did they study? What were they taught? How were they taught? What was the pedagogy?"

A curriculum should respond to the concerns of the society as highlighted in Figure 3 for curriculum outcomes and relevance. The consensus appears to be that extended degrees are 
reserved for a small minority of black students. These are programmes in science and commerce where students register for Mathematics and Physical Science or Accountancy. On completion of their first year, they may register for a medical degree, engineering or accounting, depending on the requirements set by each school or faculty.

Although statues and fees fall, a curriculum does not "fall". There have been several heated debates about "decolonising the university curriculum," but there is little innovation because knowledge systems remain rooted in colonial, apartheid and Western worldviews and epistemological and ontological beliefs. Occasionally, the curriculum is instructed in repressive classrooms by academics who lack the professional etiquette. They degrade and use their power to an extent that portrays unfair discrimination and lack of ubuntu against certain students. The curriculum and particularly its language policy and assessment process, serve to reproduce the community's wider inequalities.

It has been asserted in the context of South Africa that embracing the distinctly African philosophy of ubuntu as humanness in education can harness an enabling social environment. Through shared reflection, respect, caring and communal trust, the pedagogical cultivation of ubuntu can ensure that the education systems in Africa are not only "producing educated and trained professionals" but also "cultivated and nurtured individuals" (Waghid 2014, 66).

Students further reiterated that they are allocated off-campus accommodation, which is far from libraries and lecture halls. Transport to these residences is undependable because some of them are close to townships and are prone to strikes. In addition, internet connection is a challenge. As for white students, immediately after registration, they are accommodated on reserved residences in town where there is free $\mathrm{Wi}-\mathrm{Fi}$. In addition, computer rooms that enable the students to complete their projects and send out assignments electronically on or before the closing date are available in such residences. Transport is guaranteed every 30 minutes, and they can hop on and off near to their canteens, lectures and libraries, which has a positive bearing on their performance.

Security is always tight, and no incidents of crime have been reported, unlike in the townships where crime is extremely rampant despite security officers on duty. It is alleged that students are often mugged and lose cell phones, money and laptops. It is heart-breaking that black students who register in health sciences and commerce faculties hardly flourish, and they end up being excluded for a certain period. To re-register, the students must re-apply and go through the same mammoth process, and admission is not automatically guaranteed. Students who manage to re-register find themselves in the same predicament of not thriving, and they are barred from further registration.

Those who withstand the test of the programme, take much longer than expected. A five- 
year degree takes them seven to eight years to complete while their white counterparts complete the degree in record time. It is simple logic that equality; that is viewed as treating everyone the same and giving them the same opportunities irrespective of their individual traits, is "lip service" because it does not exist. Equity, the reckoning of differences in individual features and experiences in order to achieve equal outcomes, is a fallacy. Taking a step further, ED X abhorred,

"Black students lament and keep on sharing their experiences on social media; about the degradation and alienation treatment they are subjected to in lecture halls, of Afrikaans lecturers who label them with nicknames, and deliberately fail them and asserted that it was none of their business, if they could not understand them. In fact, they were even advised to take special classes for Afrikaans to improve their vocabulary and here, too, facilitators are Afrikaans speakers."

Student protests have been proliferating across South African universities with calls for "free, quality, diverse and transformative decolonised education" (Etheridge 2018; Pett 2015). Swain (2019) and also Smith (2012), have pointed out that this movement is indeed not peculiar to Africa. It is a global phenomenon led by the Open University where students demand the removal of "dead white men" and their values from the curricula and request the incorporation of indigenous and postcolonial thoughts and knowledges.

This maltreatment drove students to ponder movements such as \#AfrikaansMustFall, \#FeesMustFall and \#RhodesMustFall (Murris 2016, 283). It is imperative to note that higher education institutions were compelled to have an overall language switch to English, which was opposed by the pro-Afrikaner movement, most notably the civil rights group Afriforum. The group rigorously contended that, it was an unfair practice that totally discriminated against Afrikaans and further argued that, the universities must reconsider and relook at the policy reforms of terminating Afrikaans (Cherrington, Botha and Keet 2018, 2).

We should be mindful that language is a vehicle of thought and is not entirely an end in itself. For any student, there is no other means of communication easier than their own language. It must be acknowledged that it is only through the mother tongue that the student can assimilate the most difficult knowledge in the easiest possible way and can attain the capacity and efficiency for original thinking (Smith 2012,49). The banking concept coined by Freire $(1993,70)$ is an act that hinders the intellectual growth of students by figuratively speaking, converting them into comatose "receptors" and "collectors" of information that has no real connection to their lives.

This is similar to the "jug mug" notion of pouring and receiving. The teacher is the full jug and the student is the empty mug. The teacher's job is to pour knowledge from the full jug 
into the empty mug. The problem with this theory is that no student is an empty mug because all students come to any institution with knowledge of their culture. Students are passive recipients in class and now pose questions because they have a platform in their mother tongue (Freire 1993, 89). Moreover, it is only through this that an effective co-ordination between acquired knowledge and original thinking is possible, enabling one to express oneself in the most clear and direct terms with utmost robustness and credence.

The posing of questions is a testimony that demonstrates that students will display learning outcomes on completion of their programme. These outcomes are viewed as statements that describe the knowledge and skills that students should have acquired by the end of a course and that enable students to grasp why such knowledge is vital to them. See Figure 3 for outcomes.

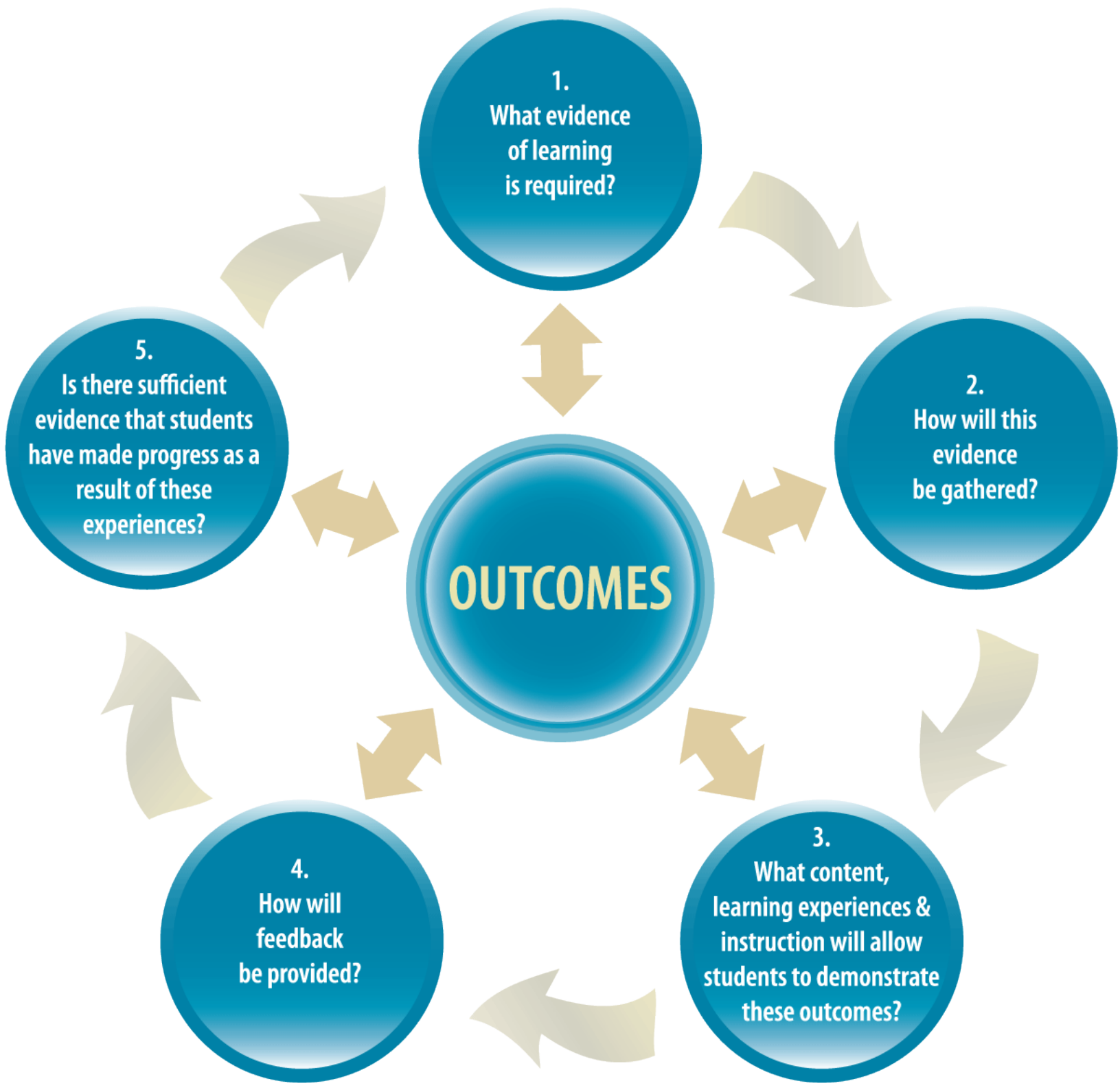

Figure 3: Curriculum outcomes and relevance 


\section{Employment practices and meetings}

An interview for a job is cumbersome but having a job interview in a foreign language is arduous. Competition is stiff, and preparation is, therefore, prudent for any academic interview. An interviewee who is a non-Afrikaans speaker becomes agitated and unsure of whether the argument in the session will be able to convince the panel members. Applicants who are Afrikaners are interviewed in their native language. Interviewees shortlisted with such applicants lose the battle before it starts. A frustrated associate professor from University A bemoaned:

"I applied for promotion to professorship in IsiXhosa. The interview was held in English and there were translation services to mollify Afrikaans speakers. Guess what happened $-92 \%$ of panel members were whites and 3\% Indians, $2 \%$ coloureds and 3\% blacks. At the end, I asked how many panel members could speak IsiXhosa, and it was only $1 \%$. The same day, a colleague from the same department who was vying for the same position with me was interviewed in Afrikaans. I did not make it in that interview whereas my colleague who can hardly greet in IsiXhosa got the nod."

A senior lecturer $\mathrm{H}$ from University B espoused the above lamentation:

"We have a black lecturer at University A with a $\mathrm{PhD}$ in Afrikaans. She was interviewed and found appointable. To our dismay, for the past five years, she has not been allowed to teach first-year students registered in Afrikaans. Reason being, it is an insult to Afrikaans speakers and it will compromise quality and does not know much about their culture. She was compelled to take other modules, which are not in her area of specialisation. At another university, a white lecturer without experience can supervise postgraduate students in SeSotho and Setswana."

When the lecturers who were unsuccessful during the interviews, demanded for an explanation about equity policy from management, they were reminded of past discrimination against them which left management on the defensive. This made academics more likely to confirm that inequities still persist. Intuitively, anyone may think, for people to understand why the employment equity policy is in place, they should explain it because of injustices that have caused some people to be discriminated against over time, which is why they were underrepresented.

This conjecture is rather sinister given the issue of social justice in the workplace. If the critique of "whiteness" can be understood as a refusal of the perpetuation of the historical prerogative in all of its manifestation, then "blackness" can transcend being expounded by howls of torture, in the face of an obstinate and all-encompassing racism and instead, position itself as an integral and equal part of humanity in dogged pursuit of excellence on a global scale 
(Nabudere 2011, 51). However, in the fast-changing world of today where everything tends to be globalised, knowing languages is an essential part of any successful plan.

Committee meetings are an example of an inherited practice in which a group of people make decisions. The identified institutions fail to practise some form of Western parliamentary procedure for their meetings. Parliamentary procedure is a set of rules for meetings that ensures that the traditional principles of equality, harmony and efficiency are kept. The thought of a three-hour committee meeting, a staple of university life, in Afrikaans fills many non-speaking Afrikaans academics with dread. They know what will happen; they will sit and listen passively, contributing only when asked and watching others dominate the space and push their own agenda. They will glare at anyone who dares to comment in Afrikaans. There are many similarities between how students experience colonial classroom practices and how these manifest in university meeting practices. In both scenarios, those who can speak are those who have the courage to do so (Wa Thiong'o 1994, 89). Others who are concerned about how their accents, use of language and lived experiences will be judged remain silent and aloof.

Even during the current COVID-19 pandemic, university meetings in this study, including departmental, faculty or college board meetings, senate and council meetings and all other academic meetings are held in Afrikaans and English. Graduation ceremonies too are conducted in the native language with some items rendered in English. English is a supporting language that is understood by most applicants who are vying for a vacancy. As English becomes the lingua franca of business and education, there are growing communities of people using English to communicate internationally with both native and non-native speakers.

Meda $(2017,7)$ cited that communicating with people from different backgrounds, who have different views of the world and different assumptions and expectations can pose its own set of challenges. Intercultural communication by nature is already fraught with the endless potential for misunderstanding and conflict. Non-Afrikaans speakers, albeit from different language and cultural backgrounds, understand what it means to be communicating in a language that is not their mother tongue (Santos 2014, 27).

\section{Research and publication}

There are "no-go" journals that are meant for the chosen few because Afrikaans is a barrier. Such journals are housed by certain universities and it is fiendishly impossible for any conducted research to be published in these journals. The mere fact that these journals are inaccessible results in the loss of many paradigms and much quality research. Some of these journals are regarded highly reputable and influential.

ED Y bemoaned that when postgraduate students complete their master's and doctoral 
degrees in English, they are compelled to translate the abstract into Afrikaans. Afrikaans-speaking students have the privilege of writing their dissertations, theses, books and book chapters in their native language. They acquire their first research output from such journals with their supervisors. There are instances in which papers submitted for publication by authors such as; students and supervisors are returned for improvement on certain aspects. Despite attending to all aspects raised in the feedback, the paper is rejected, not for the quality of research but for the quality of English. A fuming professor from University A bewailed:

"It is disheartening to note that so far, there is no accredited African language journal. Our efforts to introduce such a journal was [sic] quashed by the relevant body. Reasons furnished were, the journal was viewed as inferior and not reputable and it will not have international readers. Those who publish in Afrikaans are more privileged than non-speakers of the language."

Westaway $(2015,2)$ capitalises on such actions and posits,

"A cruel irony here is that whereas Bantu Education was explicit in wanting to reduce black Africans to 'hewers of wood and drawers of water', it actually did a better job in educating this grouping for skilled employment, than the supposedly equal education regime of the democratic government."

Such inferences are rather ominous since liberal education philosophers argue that the liberation of the mind is in the first place, more than simply preparing people for daily bread, which is what the mechanistic view does in almost all cases. Surely, a mind that is circumscribed and warped cannot be in a position to work out the solution, to the predicament that may have ruined the path of growth as a freeborn black person for so many years (Wa Thiong'o 1994, 92).

Universities, no matter where they are, ought to be places where knowledge is internalised, questioned and considered. Such knowledge should respond to the university's social, political and economic context. The pursuit of such knowledge occurs in the quest for human development (Waghid 2014, 71). Afrikaans editors and translators are always recommended by supervisors. It is a fallacy to propose that Afrikaans is superior to other African languages. That which can be articulated, studied and negotiated in one tongue can be done in any other language. It is imperative to have a political zeal to teach and augment African languages. This is a way of reinvigorating the language policy of certain universities.

Jansen $(2017,11)$ underscored that in the globalised world of the 21 st century with technology providing "access to knowledge with potential for greater participation in knowledge production", the notions of "centre versus periphery", "North versus South", "the West and the rest", white and black, settler and native are too simplistic. Indeed, global 
inequality is a reality, but democracy "opened up opportunities for Southern scholars" to engage with research programmes "with a global imprint" (Pinar 2011, 37). By substituting diversity and inclusion rhetoric for transformative efforts to promote equity and social justice, historically white universities have appeased their constituents and avoided recognisable institutional change (Spillius 2009, 11). It is time for historically white institutions in the South African higher education system, to pursue real change and forsake the mere political ploy of appeasement.

\section{DISCUSSION}

Decolonising the curriculum can mean dissimilar things to dissimilar scholars. It can be inferred from the discussion that language transformation in some universities is still a fiasco. Decolonisation is perceived as the toppling of alien rule based on violence by native liberation movements; intending to unify their nation and avail themselves of a broad spectrum of means, from peaceful negotiation to boycotts as the last resort. This prototype is partially the mirror image of the transfer of power idea. It stresses the need and urge of the colonised people to free themselves from denigration by the colonial rule. Reform-orientated tendencies on the part of the colonisers, to relinquish control are generally discerned as a tool to defuse anticolonial resistance. Students and academics too must work together in uprooting the inequality and injustices taking place in their universities. It is vital that the curriculum is decolonised so that the current education system can represent all members of society.

\section{CONCLUSION}

Although discrimination continues to exist in few South African Higher Education institutions, one can acknowledge the past and progress made by the Ministry of Higher Education in preventing it. Certain universities are hardly agencies of unprejudiced reason and veracity; instead, the curriculum and narratives they maintain are hegemonic products of centuries of cultural sway. The White, Eurocentric persuasion affects every aspect of university life, the inequitable curriculum and even the nuanced language and linguistic attributes. Apart from academic achievement, however, this restricted cultural lens that universities embody can suppress minority cultures and repress minority identity. The Eurocentric linguistic hegemony that permeates higher education is not the only drawback for minorities in the academic domain; it quells the cultural value and identity of minority social groups due to the unorthodox habitus they possess. Disproportionately vilifying the white culture and not acknowledging the fundamental benefits that it contributed will not provide the steps forward for our democratic country. It is hate-filled and divisive, as has been witnessed among its partisans. The cowardice 
and ideological viciousness of those who respond to this is petrifying. Lecture rooms that perpetuate inequalities through the use of methodologies and practices that are irrelevant to a global African university of today must be abandoned. A decolonised curriculum should, therefore, enrich and provoke minds, not indoctrinate them.

\section{REFERENCES}

Cherrington, Avivit, Marisa Botha, and Andre Keet. 2018. "Decolonising education transformation." South African Journal of Education 38(4): 1-4.

Etheridge, Jenna. 2018. "Decolonising education: How one SA university is getting it done." News 24. news24.com.

Fataar, Aslam. 2018. "Decolonising education in South Africa: Perspectives and debates." Educational Research for Social Change 7(SPE): vi-ix.

Freire, Paulo. 1993. Pedagogy of the oppressed. Revised edition. London: Penguin Books.

Gabriel, Deborah. 2019. "Enhancing higher education practice through the 3D Pedagogy Framework to decolonize, democratize and diversify the curriculum." International Journal of Technology \& Inclusive Education 8(2): 1459-1466.

Gabriel, Deborah. 2020. Teaching to transgress through 3D Pedagogy, decolonizing, democratizing and diversifying the Higher Education curriculum in transforming the Ivory Tower: Models for gender equality and social justice. London: UCL Press.

Hargreaves, Jack. 1988. Decolonisation in Africa. London: Longman.

Jansen, Jonathan. 2017. "Introduction-Part II. Decolonising the university curriculum given a dysfunctional school system." Journal of Education 68: 3-14.

Le Grange, Lesley. 2014. "Currere's active force and the Africanisation of the university curriculum." South African Journal of Higher Education 28(4): 1284-1294.

Lumadi, Mutendwahothe. 2000. "Grade 1 teachers' involvement in school-based curriculum development." Unpublished thesis. Pretoria: Unisa.

Meda, Leornardo. 2017. Decolonising the curriculum in the digital era: A student perspective. Paper presented at the International Conference on Communication and Information Science in a Science, Technology, Engineering and Mathematics (STEM) Environment. August 21-24, Caribbean Bay Hotel, Kariba, Zimbabwe.

Mudaly, Ronicka. 2018. "Towards decolonising a module in the pre-service science teacher education curriculum: The role of indigenous knowledge systems in creating spaces for transforming the curriculum." Journal of Education (University of KwaZulu-Natal) 74: 47-66.

Murris, Karin. 2016. "\#Rhodes must fall: A post humanist orientation to decolonising higher education institutions." South African Journal of Higher Education 30(3): 274-294.

Nabudere, Dani. 2011. Afrikology, philosophy and wholeness: An epistemology. Pretoria: Africa Institute of South Africa.

Odora-Hoppers, Catherine, and William Pinar. 2017. The decolonisation of South African schooling: "Looking back, looking forward", 3-12. National Education Collaboration Trust: Education Dialogue SA.

Oelofsen, Rianna. 2015. "Decolonisation of the mind and intellectual landscape." Phronimon 16(2): 130-146.

Ornstein, Allan, and Francis Hunkins. 2014. Curriculum design. In Curriculum: Foundations, principles and issues, 181-206. $6^{\text {th }}$ Edition. Boston, MA: Allyn and Bacon.

Pandey, Shikha, and Fazlur Moorad. 2003. "The decolonization of curriculum in Botswana." In International handbook of curriculum research, ed. William Pinar, 143-170. Mahwah: Lawrence 


\section{Erlbaum.}

Pett, Sarah. 2015. It's time to take the curriculum back from dead white men. The Conversation, May 8. theconversation.com.

Pinar, William. 2011. The character of curriculum studies: Building, Currere and the recurring question of the subject. New York: Palgrave MacMillan.

Santos, Boaventura. 2014. Epistemologies of the South: Justice against epistemicide. Boulder: Paradigm Publishers.

Saunders, Christopher. 2017. "Decolonisation in Southern Africa. Reflections on the Namibian and South African cases." Journal for Contemporary History 42(1): 99-114.

Sayed, Yusuf, Shireen Motala, and Nimi Hoffman. 2017. "Decolonising initial teacher education in South African universities: More than an event." Journal of Education (University of KwaZuluNatal) 68: 59-92.

Silverman, David. 2012. Doing qualitative research: A practical handbook. London: SAGE.

Smith, Linda. 2012. Decolonising methodologies: Research and indigenous peoples. London: Zed Books.

Spillius, Elizabeth. 2009. "Barack Obama tells Africa to stop blaming colonialism for problems." The Telegraph, 9 July. https:/www.telegraph.co.uk/news/worldnews/africaandindianocean/ 5778804/Barack-Obama-tells-Africa-to-stop-blaming-colonialism-for-problems.html (Accessed 11 September 2019).

Swain, Harriet. 2019. "Students want their curriculums decolonised. Are universities listening?" HSBC UK. www.theguardian.com.

UNESCO see United Nations Educational, Scientific and Cultural Organisation.

United Nations Educational, Scientific and Cultural Organisation. 2003. Education in a multicultural world. UNESCO Educational Paper. Paris: UNESCO.

Vandeyar, Saloshna. 2019. "Why decolonising the curriculum will fail?" Teaching in Higher Education 12(1): 1-14.

Waghid, Yusef. 2014. Towards an African philosophy of education. New York, NY: Routledge.

Wa Thiong'o, Ngugi. 1994. Decolonising the mind: The politics of language in African literature. Portsmouth: Heinemann.

Westaway, Arthur. 2015. Towards an explanation of the functionality of South Africa's "dysfunctional" schools. Seminar Paper, Unit for the Humanities at Rhodes University (UHURU), 25 February. 